\title{
INTERNATIONAL TOPICS IN CENTRAL AMERICA'S THOUGHT AND AGENDA, 1900 - 2010. A FRAMEWORK IN FIVE MOMENTS ${ }^{1}$
}

\author{
Los temas internacionales en el pensamiento y en la agenda de Centroamérica, \\ 1900-2010. Un esquema en cinco momentos
}

Eduardo Devés-Valdés*

\begin{abstract}
Between the beginning of the 20th century and 2010 several moments can be noted in the discussion of Central American thought and in the creation of an agenda in regards to international and world affairs, revealing some topics and concepts that are sustained throughout the century, while others are renewed. This paper establishes a chronological
\end{abstract}

\footnotetext{
1 This article is the product of the project "El pensamiento latinoamericano sobre asuntos internacionales en el siglo XX", from the Fondo de Investigación Científica y Tecnológica, Fondecyt No 1110860, from conicyt-Chile. I thank professor Carlos Horta and the Biblioteca de la Carrera de Estudios Internacionales de la Universidad Nacional de Costa Rica in Heredia, especially the librarian Marianela De la O.
}

Este artículo fue enviado a revisión inicialmente en español y ha sido traducido al inglés gracias al Proyecto FP150008, "Aumento y mejora del índice de impacto y de la internacionalización de la revista Universum por medio de la publicación de un mayor número de artículos en inglés". Fondo de Publicación de Revistas Científicas 2015, Programa de Información Científica, Comisión Nacional de Investigación Científica y Tecnológica (Conicyt), Chile.

This paper was initially sent for review in Spanish, and it has been translated into English with the support of the Project FP150008, "Aumento y mejora del índice de impacto y de la internacionalización de la revista Universum por medio de la publicación de un mayor número de artículos en inglés." Fund for publication of Scientific Journals 2015, Scientific Information Program, Scientific and Technological Research National Commission (Conicyt), Chile.

* Professor and investigator of the Instituto de Estudios Avanzados in the Universidad de Santiago de Chile. Email: eduardo.deves@usach.cl,www.eduardodevesvaldes.cl

Article received June 27, 2015. Accepted September 4, 2015. 
framework of five moments in the development of ideas, focusing on the most relevant concepts and the protagonists in the discussions. It attempts to highlight what distinguishes Central American works from those elaborated in other regions of Latin America.

Keywords: Central American thought, international affairs thought, Central American integration, unionism, international agenda.

\section{RESUMEN}

Entre comienzos del siglo XX y 2010 pueden distinguirse varios momentos en la discusión del pensamiento centroamericano y en la formulación de una agenda acerca de asuntos internacionales y mundiales, donde se relevan algunos temas y conceptos que atraviesan el siglo, así como otros que se van renovando. Se establece una periodización con 5 momentos en el desarrollo de las ideas, destacando los conceptos más relevantes y quienes son protagonistas en las discusiones. Se intenta destacar lo que distingue las elaboraciones centroamericanas de las realizadas en otros lugares de América Latina.

Palabras clave: Pensamiento centroamericano, pensamiento asuntos internacionales, integración centroamericana, unionismo, agenda internacional.

\section{INTRODUCTION}

Studies about Latin American thought have been broadening systematically. The concern regarding international affairs are already topics for those in this field, and includes a growing bibliography.

The principal hypothesis presented in this work is that there exists a Central American thought about the region and its relationships with the world. This thought is not focused on the nation-state $(\mathrm{N}-\mathrm{S})$ as the only protagonists, but the region as a whole, and alludes to the participation amongst diverse players. Actually, in Latin America (LA) there exists a thought path that does not only deal with international and world affairs in regards to the N-S, but also the region or sub-regions. Consequently, they have developed the following issues, just as the other outlying regions: regional integration, the relationship between the center and outskirts, dependence, regional peace, anti-interventionism, anti-imperialism, and intra-regional conflicts.

This article tries to determine what have been the main points of discussion in Central American thought, detecting in what moment new topics were introduced that reformulated the agenda. The new topics displaced the importance of the previous ones, even though they normally do not disappear but survive and 
became reinterpreted. To clarify, even if just partially, we will go through 3 paths: What have some of the principle figures planted? What have been the issues that have been formulated? Which concepts have been elaborated because of it?

It should be noted that it does not only refer to thinking as the nation-state, but thinking of the region as organisms beyond-nationality, academia, intellectual networks, political parties, social and work organizations, it is to say, groups that contribute, although not equally, in the development of the agenda. It should also be considered that there exists a particular interaction between the international agenda of the States and some Latin American intellectuals, principally associated to the CEPAL and FLACSO. Obviously, one cannot think that the topics and agenda are only created from the Central American region. Some topics clearly come from the United States agenda and others from the Latin American and world discussion. The topic of anti-imperialism, and especially unionism, are incomprehensible without extra-regional figures like José Vasconcelos, Víctor Haya de la Torre and APRA, and later Raúl Prebisch and CEPAL. Of course, it does not mean that there has not existed a Central American way in approaching the topics, firstly consisting in the search for Central American applications, but also a specific way of conceiving them, at least in some cases.

There is little space in an article to present the 5 moments, for that reason it will be done in a concise manner, taking advantage of the summaries that have been previously presented by people who have studied specific aspects.

Lastly, keep in mind that this article studies the discussion and creation of ideas, not the effects of outside politics of the N-S, and even less if they were a consequence of the ideas expressed.

\section{THE FIRST MOMENT 1910S - 1940S: UNIONISM, ANTI- INTERVENTIONISM, ANTI-IMPERIALISM...}

Since the end of the XIX century the union proposals have repeated as part of the agenda of governments attempting successive and ambitious projects (see Antillón 1996). Early in the 20th century a thought of unionism and antiimperialism, at least anti-US-Americanism ${ }^{2}$, was being built. The most important figure in the creation of this was Nicaraguan Salvador Mendieta, putting a

\footnotetext{
${ }^{2}$ I prefer to use the word "US-Americanism" for the people of the United States of America, of wide use in Spanish, like it will be found on the internet, in addition, it's accepted by the RAE in exchange for the improper "American" and "American of the North" or "North American" for the expression "citizen of the United States of America" for being long and not to use something informal like the Spanish term "estadounidense".
} 
concentrated effort through networks connecting numerous intellectuals and politicians. The Partido Unionista Centroamericano (founded in 1899), Central American studies, and the interaction of these networks with post-revolutionary Mexico played an important role in the effort. The systematic creation of networks created by Mendieta and others took effect during moments in which exposure to Mexico's culture, intellect, politics, to José Vasconcelos' in particular, as well as the emerging APRA developing similar concepts.

Within this framework, J. Cecilio del Valle devised the proposal to recreate the Great Homeland. Teresa García G. stated,

"from the social spaces of university graduates, professionals and workers, the debate formed around the need to unify popular sectors through a series of common objectives. The first of those was the fall of Estrada Cabrera; others were the fight against imperialism and national oligarchies; everything was from the regenerative perspective, in which pan-Hispanic movement played a relevant role" $(2003,1)$.

Ideas concerning international matters became more expressive and insistent for the purpose of Sandino's fight in the latter half of the 1920s. Sandino himself, like those who express solidarity in their beliefs, reiterated the denouncement of imperialism and its policies. The movement tried to avoid the colonization of Central America (CA) by denouncing the Monroe Doctrine and insisting on the necessity of a Latin American meeting to take on these challenges. Sandino affirmed, "I will see to the abolition of the Monroe Doctrine, which I believe to be unnecessary, thus it is now time that the tutelage over Latin countries in the New Continent disappears, whose independence has reached maturity (cited in Cuevas 2008, 203). Rafael Cuevas affirms what Sandino proposed, furthermore "establishing the Latin American nationality and making it effective," which implicates:

"establishing periodic meetings; establishing a Latin American court of justice; organizing an army; enforcing measures against any aggressor towards a Latin American country; a Latin American bank committee that could permit the cancellation of existing contracts with the United States and the construction of infrastructure projects; reestablishing Latin American sovereignty over the Panama Canal; demanding that intervening countries vacate" $(2008,202)$.

In the mid-1930s Mendieta returned to these matters in his work Alrededor del problema unionista americano [All around the American Unionist Problem], published in 1934, heavily criticizing the US-American intervention in Nicaragua, while at the same time arguing in favor of the unity of the Isthmus. According 
to him, unity meant strength for CA, because separatism was a synonym for the final collapse before imperialism (1934, Vol. II, 436). He thought that unionism's openness to the world would contrast with the blind localism of the separatists, the downfall of the region (1934, Vol. II, 421 and 437). Appealing to the Partido Unionista Centroamericano for action, Mendieta proposed the creation of a National Constituent Assembly that would eliminate the governments and organize a federal nation, hoping that the Federal Republic of Central America would convert into a beacon of democracy, unity between Spanish-Portuguese speakers, peace, tolerance, and justice (1934, Vol. II, 452).

Included in these ideas and networks were figures like the El Salvadorian Alberto Masferrer, the Guatemalan Carlos Wild Ospina and the Colombian, wellknown in CA, Porfirio Barba Jacob, who according to Marta Casaus' plan, shared a political project to unite Latin Americans of the region under the flag of unionism with the purpose of fighting for national sovereignty, marching into Nicaragua, Panama, and other Latin American nations. Their anti-imperialism had roots more persistent and spiritual than the Marxists and Sandino, Ugarte, Mariátegui, and Haya de la Torre's fight appeared to be their guides; all of them belonged to various Latin American and international anti-imperialism leagues (2011: 116).

\section{SECOND MOMENT 1940S-1950S: CENTRAL AMERICAN NATIONALISM, DEMOCRACY, CONTINENTAL UNITY...}

The second moment represents a small change within an important continuity, both the type of discourse and in the kind of institutionalization. The Unión Democrática Centroamericana (UDC) was the key component in the creation of this thought during this time period. There converged figures like Vicente Sáenz, Rafael Heliodoro Valle, Mario Sancho, Carmen Lyra, Mauricio Magdaleno and Clemente Marroquín, among others. UDC's fundamental rationale was that there existed a relationship between Central American unity and democracy. It developed in such a way that democracy was correlative to the advance of continental unity or the advancement of good relationships between countries. Democracy opposed dictatorships, which were almost synonymous for isolation, distrust, and disunity between nations. These ideas counted on the support of the Guatemalan State with figures such as Juan José Arévalo and Jacobo Arbenz, and later the Costa Rican José Figueres.

Unionism networks, pro-democracy sentiment, and defense of CA's wealth were expanding and strengthening together with defining objectives. Margarita Silva illustrates that in the framework of the Partido Unionista Centroamericano three branches were established: the Frente Unionista Nacional Centroamericano 
located in El Salvador, the Frente Unionista Democrático Centroamericano established in San José, and the Frente Democrático Guatemalteco. These "had in common a base program inspired by the Atlantic Charter, the conquests of the Mexican Revolution, the Good Neighbor policy by President Franklin Roosevelt," and within their objectives were "the reunification of CA, the defense of liberty and democracy, the nationalization of public services of transportation, electrical communication, irrigation, and the establishment of insurance, rural banks, and marine and aerial navigation" (2014: 42).

Another initiative of these networks was the official publication by the UDC, Centro América Libre [Free Central America], "in which Vicente Sáenz, Rafael Heliodoro Valle, Mauricio Magdaleno, Alfonso Reyes and Clemente Marroquín, among others, regularly collaborated" (Chapa Bezanilla, 2008: 195). Sáenz, Arévalo and others, linked nationalism, anti-imperialism, and Central American unity. On his part, Valle emphasized uniting customs, eliminating passports, and constructing routes to make commercial transactions and interaction between towns easier (see Chapa Bezanilla, 2008: 196). Juan José Arévalo also supported that the Federal Republic of Central America would terminate allpowerful leaders, self-serving, with voracious individuals that use public wealth, and with rural governors that lack spiritual concerns and meander clumsily even in their personal lives. In summary, for him it was practically an axiom that the federation would favor democracy (1946: 68). Now, this Federal Republic of Central America was not a myth, but a short-term possibility. The only thing missing is that all five presidents meet to announce to the people the renouncing of all future presidencies, to promise to give absolute electoral freedom, in one word, to return America to the Central American nation it was a century ago (1946: 197). According to Arévalo, democracy strengthened security and peace. The governments chosen by the popular institution were more constructive and more secure from every point of view than those organized behind the backs of the people. The federation would have already been made if the governments would have laid down their personal interests. This joins with the idea that Nazism is equivalent to anti-democracy and insecurity, which has provoked the World War, in other words, it indicates that democracy is equal to peace and concordance between the people (1946: 196-197).

Complementing Vicente Sáenz, he pointed out the importance of peace between the five States, helping one another mutually (remember that Panama and Belize are not considered part of the CA at this time), studying and resolving their own problems, merging again as one and free nation, and being conscious of their rights and obligations; that could have been a model of wisdom, true democracy and justice in front of the rest of the countries in America and the world (1954: 48). Said in another way, the totalitarian dictators represented a serious danger 
for unity, solidarity, peace, and defense of the continent because it was impossible to expect honest collaboration from them and effectively develop democracy, in a time of war and in a time of peace (Sáenz, 1946: 25-26) ${ }^{3}$. The defense of resources appeared crucial to Sáenz. Arguing, "How have we not cried against the lack vision or other matters of our own leaders, saviors of the homeland, but supporters, along with our ministers and diplomats, of the monstrous concessions that they have wrapped around our necks?" The Central American situation is dramatic and it will be while the tyrants of Isthmus, supported by the "loans and leases" of the great imperial eagle survive (cited by Zeledón Cambronero, 1977: 276 and 278). José Figueres echoed these ideas while undertaking the presidency of Costa Rica. In La Habana during the Conferencia Interamericana sobre Democracia y Libertad [Inter-American Conference about Democracy and Liberty] of 1950, he affirmed "The union seems impossible if posed in a political light and in its totality: merging a whole hemisphere into one nation, or at least 19 Latin American republics." But Figueres pointed out, "there are bonds less ambitious that can be stretched: the union of geographic zones and within them the merging of certain features, like the economy and education. Culture drives the union and the merging of resources will expand culture. Both things together, union and culture, are the permanent remedy for our poor economies and for our bad politics." $\mathrm{He}$ commented on cultural political matters with the economy, affirming that "the principal objective of human effort in the second half of the twentieth century is to end misery. For that reason, efficient methods are needed for the production of wealth". But it is impossible "to end poverty of the majority without at least talking about wide economic comprehension with the nations' neighbors. The economic union is the first step towards the faraway ideal of a political union. And the economic union is possible in our time. And is more than possible, essential" (cited by Vargas 1990, s/p).

These ideas and networks resulted in advances that had not happened before the foreign policy and the union of CA. In October of 1951, the Organización de Estados Centroamericanos [Organization of Central American States] (ODECA) was created.

\footnotetext{
${ }^{3}$ The Central America proposal was sustained by other Latin American figures like Venezuelan Rómulo Bentancourt and the Peruvian V. R. Haya de la Torre. This relationship between democracyinternational cooperation they believe favors protection for the economy of the committed countries.
} 


\section{THIRD MOMENT 1950S-1970S: INTEGRATION, DEVELOPMENT, WEALTH DEFENSE}

Figueres' sentences about the importance of the economy are statements that are opening doors so that soon CEPAL's integration paradigm will be installed, corresponding or making development easier. The ideas expressed during this third moment can be summarized in three greater themes, as well as other smaller ones. The development transformed the old theme of unionism to now integrationism; the creation of permanent institutions that embody the integrationist intentions; and the defense and recuperation of wealth, which are very necessary to advance development, formulation of the last is associated with anti-imperialist and antiinterventionists statements of the previous decades.

Integration, a strong notion linked to development that has marked the whole second half of the twentieth century and up to the beginning of the twenty-first century. In this era "development" was conceived as "replacement of importation", it means an "inward" development. So, this integration focuses on intra-regional commercial growth, common tariffs, the Central American Bank for Economic Integration, and expanding transportation and communication networks, among other elements. The objectives of the Mercado Común Centroamericano [Common Market of Central America] (MCCA), which took effect in 1961, having been summarized by Dunnia Marín and Max Sáurez, they consisted of "reaffirming their purpose of unifying the economies of countries and boosting together the development of CA with the goal of bettering the lives of its inhabitants. For that reason, it intended to promote the industrialization of CA and at the same time reduce its members' dependency on primary products, for which specific objectives were presented: merge towards a common foreign tariff, establish a common market, promote and coordinate industrial development, cooperate in monetary and financial areas, develop integrated infrastructure, and facilitate intraregional inversion (see Dunnia Marín and Max Sáurez, 2014).

However, the relationship between development and integration was not obvious. In 1968, Isaac Cohen opposed a functionalist to a federalist integration inspired by the European example like it had been previously imagined, aiming to build a sort of nation-state framework. This means that "the tentative, consensual, functionalist pragmatics have permitted the 5 countries to reach relative success in matters of integration, if it's compared to the previous endeavors and other trials undertaken by countries on paths to development" (1968: 170). The gradual and progressive focus "is to be completely in agreement with the functionalist strategy that consists in indicating immediate objectives or necessities, so that differences do not exist between the agents in the process", leaving the fundamental matters and long-term objectives for the future (1968: 172). According to Cohen, in the 
case of Central America, citing a CEPAL document Integración y reciprocidad en Centroamérica [Integration and Reciprocity in Central America], the approach consisted,

"in politics that, within the general framework for economic development, tends to optimize localization for some important economic activities, especially those of industrial character and the changing of agriculture/livestock products and minerals with vision to establish production units of adequate size" (s/f 35 ).

In this way, it would be possible to establish new industries that never have been viable before if only supported by the national market, and in place of establishing 5 or more factories too small, "a study would track down the most efficient size, located in those sites that were most convenient and economical from the point of view of the whole region" (s/f, 37-38). In other words, it is not about the establishment of a customs union, nor an association of free commerce, but a better set-up of new particular industrial activities in a region, whose viability would be impossible in every one of the countries in the area, but that the satisfaction of a wider market would give them the possibility to function more efficiently. So that more inversion is not generated in one area over another, "the CEPAL supports the proposal called "beginning reciprocity", also known as "balanced development" (1968: 172-173).

A second important topic was the necessary creation of institutions that embodied integrationism. This was linked to a discussion that has been occurring since the 1940s with a lot of momentum and even before then. Actually, it had already been built by the Consejo Superior Universitario Centroamericano [Central American Superior University Council] (CSUCA) in 1948 and integrated by the public universities; later the Central American Institute of Public Administration (ICAP) in 1954, like the Escuela Superior de Administración Pública de América Central [School of Public Administration in Central America] (ESAPAC) was transformed in 1967 to ICAP (Delgado Rojas 2014, 108). In 1951 the Minister of Foreign Affairs of El Salvador called for a meeting with his peers from the remaining Central American countries. From there resulted the declaration,

"From this first meeting of chancellors a solution could not be found for the particular problem, for that we need the creation of an organism that can permanently dedicate itself to searching for appropriate solutions, it is the only practical solution for those of us who have the final decision to become united from our States for the means of progress and pacific cooperation among them." 
This reunion gave origin to the Carta de la Organización de los Estados Centroamericanos [Central American States Organization Charter] (ODECA). Ana Elizabeth Villalta has highlighted that the time that was spent searching for better political ties through the creation of the ODECA, "also procured better economic ties, and this is how the CEPAL meeting of 1951 agreed upon a request to the Central American governments for the formation of the Comité de Cooperación Económica del Istmo Centroamericano [Economic Cooperation Committee of the Central American Isthmus]." It was this committee, reunited for the first time in Tegucigalpa in 1952, that started "the process of Central American economic integration, with the goal of reaching a true common market (s/f, 142). The discussion about the necessary institutions continued, occurring a decade later and emphasizing the scope of the economic process of the Mercado Común Centroamericano in 1960.

A third relevant topic was the defense of wealth. Defending himself, Omar Torrijos put in the Central Americanist trajectory "My ideology? I am Figuerist!" That was featured in a collective criticism, mostly formulated in third world discourse: political and economic independence, backed upon the aspirations of third world people that fight against foreign oppression to win their true freedom, defense of basic wealth, principles of international law, respect of the people's selfdetermination and sovereignty of the States. For Torrijos, the integration of the people of LA was a key that became almost necessary, as the legacy of "the great thought of our liberators and the commitment to making togetherness a reality" for the authentic integration of LA. It took on, in consequence, like a way to express the formation of multinational Latin American businesses", which should have played a fundamental role in the integration of the region (s/f 277-278). This union was conceived as part of a larger project that consisted in the fight to liberate towns of the third world to gain true political and economic independence, backed upon the aspirations of third world towns that fight against foreign oppression and win their true freedom ( $\mathrm{s} / \mathrm{f} 240$ ). According to what was presented, these towns fought so that their non-renewable resources did not support the economies of the rich countries. They desired that the wealth of their land have the nationality that possessed it because this is an inherent right, like it is in an inherent right of Panama to exploit its geographic position in benefit of its own development. This, insisted Torrijos, because we cannot accept the economic submission of one country over another, nor political, cultural, or economic infiltration because this is no more than neocolonialism; That is to say a refined colonialism, a disguised colonialism that has been present in our people through conditional economic help that does not look for the development of our country, but the control of its people (s/f 223-224) and more broadly, their common anti-imperialist position against all the centers of international economic, political, and ideological power; 
their uncompromising defense of self-determination, sovereignty of their people, and their undeviating aspiration to build in their countries new forms of truly democratic organization (s/f 239).

Even though Torrijos did not signal it, he was in harmony with the work of Vicente Sáenz who had echoed the processes of decolonization and the third worldism which, by the way, had relatively little repercussions in Our-America. In Rompiendo cadenas [Breaking Chains], he emphasized his independent position, third worldism, deep commitment to every town that fights for their liberation, and opposition to all types of genocide (cited in Zeledón, 1977: 279).

To a lesser extent appear other topics, some which will grow to be important; within those the topics are the environment, the pacific use of nuclear energy, the necessity to increase embassies, greater international presence and inclusion, and support of the 200 maritime miles. In 1975 Omar Torrijos and Daniel Oduber, president of Costa Rica, along with the presidents of Colombia and Venezuela, introduced a new element to the agenda. It declared that "even though the pacific use of nuclear energy is necessary progress and beneficial, the leaders condemn experimentation by the world powers and proliferation of nuclear weapons in conditions that could affect peace, ecological balance, and the environment in any region of the world" (Torrijos s/f, 277).

\section{FOURTH MOMENT 1970S-1990S: DISARMAMENT, PEACE, DEMOCRACY, DEVELOPMENT...}

The outbreak of violence at the end of the 1970s was a phenomenon of international character and left CA visualized as a violent region, it produced such an impact that peace was becoming a key concept, which created a discussion that capitalized and reformulated previous concepts. In these years, various concepts with a trajectory, such as development, justice, democracy, and integration communicated peace and human rights. The topic of peace was the most specific and was a different way in expressing ideas about democracy and human rights, as compared to other regions of Our-America, where the civil wars and their contaminative effect on international affairs were not present.

But this is not only about a peace/violence problem. Whether it is or is not in coherence, a relative feeling had been talked about since the end of the 1970 s in regards to the principal international project of CA, the regional unionintegration, which did not work like it should have and there were even voices that suggested eliminating it, looking for insertion of every economy in the international market. Gert Rosenthal stated that "unfortunately, in many circles, there is resignation towards the so-called "crisis" for integration that has converted 
into something permanent" (1979: 5). Actually, it refers to a "vicious cycle where 'economic nationalism' grows from the result of a loss of confidence that is inherent to the integration crisis" (1979: 7), even though the results were rather obvious "the advantages of economic integration are for small countries that also have a high degree of homogeneity" (1979: 6). Rosenthal pointed out that the proposal of the pioneers about economic integration in the 1950s, articulating integration concepts and continuous development was still present by the end of the 1970s (1979: 7). For restarting the process, removing the part of crisis that bogged it down required that "the entities in service of integration identify the aspects of interest for all countries, permitting the situating of regional topics among topics of priority at every level" (1979: 17). Meanwhile, to advance this in the first place, the culmination of a mediation process that guided the governments of El Salvador and Honduras would be necessary; in second place, the adherence to a framework treaty, whose main proposals would articulate the big objectives of the process, third place, the adoption of a special regimen that permits some countries to fulfill integrated promises with less speed than others, and in fourth place, and perhaps the most important support, the adoption of a short-term action program that gives real context to the tools previously written (1979: 17-18).

The proposal of Rosenthal did not have and perhaps could not have had too much echo in that moment, in the face of the urgency of other matters that clouded and slow downed the integrationist process. The Panamanian Oyden Ortega-Durán showed that in 1983 it was clear for the ministers of foreign affairs of Contadora, a group in which he participated, "that the matters of priority were: the arms race, arms control, their reduction, arms trafficking, the presence of military counsel and other forms of foreign military assistance, actions aimed at destabilizing the internal order of other States, threats and verbal aggressions, warlike incidents and border tensions, human rights violation, individual and social guarantees, just as the grave problems of economic and social order that are the foundation of the crisis and affect the region" (Ortega-Durán 1985, cited in Antillón, 1997: 22).

Peace was imagined as "possible through international help and the willingness of the Central American States" and in this framework Contadura and Esquipulas were developed at the beginning of 1986 (Villalta s/f 144). There a new form of discussion about international affairs was crystalized, in this way the Declaration of Esquipulas I already recognized that peace "can only be fruit of a process that is democratic, pluralist, and inclusive that implies the promotion of social justice, the respect of human rights and Central American self-determination, the territorial sovereignty and integrity between the states, and the right for all nations to selfdetermine". The topic of peace was transformed into the key that displaced all the others from being first in importance, although it was linked to them. 
Francisco Rojas Aravena has summarized the new conceptual plot in the following way: "The concepts of peace-democracy-development were placed in the center of negotiating". The essential piece was that "the democratic path was opening a route between the polarized options of revolution and anti-revolution", in this way it argued about the foundation of a virtuous cycle where reaching peace is "reaching a minimum of prosperity and that the fruits of development are divided based on the criteria of justice and social equality. When there is no development, it will not be possible to find peace and overcome the injustices. Without peace there will not be a stable political regimen founded in tolerance and in consensus" (1990: 20). These three concepts were still linked to the others, like security, cooperation, national reconciliation and integration, it is to say, it was understood that to accomplish everything a team effort was necessary to resolve the group of matters "called the six Ds: democracy, development, debt, disarmament, drugs, deforestation” (1990:180-181, 202).

That allowed for the detection of various smaller topics, some which reached greater prevalence in the following period. To note, they are: international cooperation, drug trafficking, and the environment. On another front, the Nicaraguan essayist Julio Ycaza Tigerino put on the table the growth of the Spanish language and how this made more evident the unity with Spain, which deduced a need for a project of Hispanic American unity, a Hispanic Community of nations united by tongue and by Catholicism (see Giménez 2002: 22).

\section{FIFTH MOMENT 1990S-2010: OPEN INTEGRATION, SUSTAINABLE DEVELOPMENT, DEMOCRACY, SECURITY...}

The signing of the Esquipulas agreements, that reached important consensuses in respect to the topic of peace, led consequently to diminishing the importance of this, speaking as if it was already accomplished. In Tegucigalpa in 1991, Central American presidents subscribed to the "Tegucigalpa Protocol", where concepts like "a region of peace, liberty, democracy, and development" were handled, by this means they created the Central American Integration System (SICA), which strongly put topic of integration on the table again, even though linked to peace, integration appears as a way to guarantee it. This affected the

creation of a new agenda which was influenced by the States, the academia and more widely the intellectuality, with a greater rural professionalization, and international bodies, keeping in mind the broad Central American institutionalization, that had been constructed during the whole second half of the twentieth century. Thus, the discussion progressively identified new topics, new concepts, and new objectives. They resumed topics with long trajectories like integration and development, but 
are now not related to the war but other emerging topics, in particular security and international insertion. Between the end of the 1980s and the beginning of the 1990 s, a significant change was produced. In reference to this, Víctor Hugo Blanco (2014: 75-76) showed that the Tegucigalpa Protocol reaffirmed the following purposes, among others: consolidate democracy, strengthen institutions and respect human rights, pinpoint a new model of regional security, overcome extreme poverty, promotion of sustained development, the protection of the environment, the eradication of violence, corruption, terrorism, and drug and arms trafficking, accomplish an economic union and strengthen the Central American finance system, strengthen the region as an economic block to successfully introduce it to the international economy, and creating the Central American Integration System.

\section{A- OPEN INTEGRATION, SOCIETY,AND INTERNATIONAL INSERTION}

The topic of Central American union, with its nuances, has maintained completely current in public discussion, in part by some N-S officials, academia, politics, and international bodies. The creation of SICA in 1991 marked the restarting of the integrationist initiative. From here came the idea of "open integration" for the international insertion, more than a defensive and antiimperialist integration; it was an integration associated with development after the lost decade of the 1980s, aiming to overcome poverty. Presidential meetings throughout the decade of the 1990s and the 2000s reiterated this matter, academic meetings and diverse publications have continued considering it. This economic integration was associated also with the customs union, free mobility of products, and monetary and financial integration.

Gert Rosenthal pointed out that at the beginning of the 1990s a shift had been produced in the argumentation in respect to the matter of integration and with its own discourse emphasized other elements. It argued that "originally thought as an instrument of collective defense against the emerging adversities in the foreign sector, today it stretches to form an element more offensive that contributes to a better international integration for Latin America” (1991: 63). For his part, Alcides Hernández Chávez (1992) throughout those same years wrote about a "new Central American integration" and later Willy Soto (2014: 68-69) insisted on the same notion, calling it new economic integration after the pacification. "New" was produced after the hard hit that the violence delivered to MCCA". In the final declaration of the VIII Cumbre Presidencial (Antigua) de Jefes de Estado [VIII Presidential Summit Meeting (Antigua) of the Chiefs of State] in 1990, it defined that from here on out that the regionalism stance would be open to promising itself to: 
"Boost the sustainable development of Central America through a common strategy towards the outside. Restructuring, strengthening, and reactivating the process of integration, like the regional Central American bodies, adapting or redesigning their legal and institutional framework to brand them with renewed momentum and facilitate their adaptation to new strategies of foreign openness and productive modernization that the Central American countries undertake, aspiring to the formation and consolidation of the Economic Community of the Central American Isthmus".

This new integration has been considered, like never before in the agenda, the concern of civil society. Ricardo Sol noted that the Advisory Committee of SICA, in agreement with the Tegucigalpa Protocol, "will be integrated through business, labor, and academic sectors and other principal dynamic efforts represented by the economic, social, and cultural sectors, committed to the integration effort" (2012: 64). The AC-SICA was formally created in 1996, after 18 organizations signed the act and constituting statutes. Jaime Delgado Rojas adds that this participation does not deplete in this body, since "there are other facets of social life that deepen regional unity and does not reduce formal participation in AC-SICA", including "business life, big and small trade, family networks, ethnicities and multicultural, but above all, the migration that has made a "Central American citizen" possible (2014: 114).

On their side, indigenous populations have felt invited to express their voice in regards to the integrationist process. The collective CICA has stamped their desire to participate by claiming "full participation in the new regional integration" (2007: 10). In that respect, it shows that

"fully convinced about the cosmological, spiritual, and philosophical content of our culture, we are building strategies that are included in the regional integration process and for that matter we have started in this century and for what is foreseen for us as the beginning of a new era where our People can play an active role in the construction of our destiny and development" (CICA 2007, 4).

During the fifth moment in the discussion about the Central American international agenda, the topic of migration acquired a greater and prominent relevance than in previous times. For example, the president of Guatemala, Oscar Berger, highlighted the importance of the work of undocumented workers for the economy of the United States, with their work they collaborate equally "with the economy of the United States and with the development of our countries", additionally presenting that it was necessary "to unite efforts" to defend the interests of the immigrants" (cited in Delgado 2014: 112). In 1996, the Conferencia Regional sobre Migración [Regional Congress for Migration] took place, formed by 
six Central American nations, Canada, the United States, Mexico, the Dominican Republic, and with the presence of civil society organizations. The plan created has three strands: politics and migration management, human rights, migration and development, to assist and reduce the vulnerability of these populations in the commission's members' countries (see Delgado, 2014: 112).

\section{B-SUSTAINABLE DEVELOPMENT AND THE ENVIRONMENT}

The topic of development has been inseparable from the discussions about environmental sustainability. Gabriel Aguilera has argued that they could have formed an "ecological ideology", elaborated within the setting of the re-launch of integration. "The re-launching of integration along with the creation of SICA, the signing of the Protocolo al Tratado General de Integración Económica Centroamericana [General Treaty of Central American Economic Integration] in 1993 allowed interregional trade to normalize. In this setting, the Central American presidents reflected that "there was a lack of ideological framework for the new integration process and there they agreed on the concept of the Alianza para el Desarollo Sostenible [Alliance of Sustainable Development] (ALIDES), which links integration with sustainable development and democracy". Adding to the principles of that concept includes:

“1. Respect life in all of its forms 2. Improve humans' quality of life 3. Respect and take advantage of the vitality of the earth in a sustainable way 4 . Promote peace and democracy as basic requirements for harmonious living 5. Respect diverse cultures and ethnicities in the region 6. Accomplish better economic integration between countries of the region and of the world 7 . Cross-generational responsibility in sustainable development" (Aguilera 2012, 88).

Numerous contributions have underlined the importance of environmental matters as an international problem. For Richard Sol, "the creation of ALIDES through the Declaration of Guacimo in 1994 and the Cumbre Ecológica Centroamericana para el Desarrollo Sostenible [Central American Ecological Summit for Sustainable Development] of the same year created an advance of invaluable importance" (cited in Ordoñez and Gamboa 1997, 26). For Gabriela Grynspan, Vicepresident of Costa Rica, "ALIDES assumes the first integral and systematic attempt to define policy for regional development that devises economic growth on behalf of the protection of natural resources and of the sustainability of distinct natural and human factors", and makes us understand the significance of it, "it is the most important governmental consensus of regional character after Esquipulas, II" (cited in Ordoñez and Gamboa, 1997: 26). 


\section{C- SECURITY AS THE BACKBONE}

The problem of security is probably the most argued about in this fifth moment, just as much because of the state agents as the academia. In regards to that, one tries to think about the recent trajectory of foreign affairs as also society models and integration of the future.

Rodolfo Cerdas realized an important distinction at the end the 1990s for showing mutation in a way to understand security. According to Cerdas "the military aspect had declined in importance and stopped being a fundamental pillar of the new security problems". This implied "a process of conceptual and doctrinal redefinition put on the agenda, placing the military aspect in a much more widened and all-encompassing context" (1998: 122-123).

The topic of war and peace affected the way of thinking about CA, exacerbated by a historic concern about the danger of dictators and the psychosis of insecurity that comes from the agenda of the empowered. Thus, a thought of "omni-security" was maturing, not to mention the reflection of international affairs permeating the search for security, in a setting that would later conceive the topic of drug trafficking, gangs, environmental issues and other matters that, under this lens, came to justify it. It means, for a good part, if not all of the topics, were seen through the lens of security.

In relation to that, a security agenda was argued about, its inexistence and necessity. Gabriel Aguilera commented in 1995, even though "a security agenda accepted by all the countries in the region does not formally exist", there does exist central elements of the same that "are part of the agreement SICA creates and that repeat in the project of the Acuerdo Centroamericano de Seguridad [Central American Security Agreement] that the Commission of Esquipulas created" (1995: 120). Aguilera continued pointing out that SICA had hopes to finalize a new model of regional security:

"sustained by a reasonable balance of powers, strengthening of civil power, overcoming extreme poverty, promotion of sustained development, protection of the environment, the eradication of violence, corruption, terrorism, drug trafficking, and arms trafficking" (cited in Aguilera, 1995:125-126).

For Rojas Aravena the solution to the regional problems, in particular governability, would only be possible as "cooperative and participative solutions at

\footnotetext{
${ }^{4}$ I understand that "omni-security" refers to all or a large part of the problems a society has due to matters of security. This contrasts, for example, with other moments in which these same problems were seen to be related to development.
} 
the national and as well as in the regional level, in a setting of growing integration and security. For living free of hunger and inequality, societies also have to be free of fear. Democratic governability depends on a combination" (Rojas Aravena, 2008: 10). Rojas Aravena and Tatiana Beirute broaden this agenda to drug, small weapons, and light arms trafficking, treatment of people and migration, money-laundering, gangs, corruption, impunity, private security businesses and shortfalls of the Constitutional State (Rojas and Beirute, 2008: 15). This "omnisecurity" is connected by Delgado Rojas with the peace treaties of Esquipulas that aim at a security model "sustained regionally by a reasonable balance of powers, strengthening of civil power, overcoming extreme poverty, promotion of sustained development, protection of the environment, the eradication of violence, corruption, terrorism, drug trafficking, and arms trafficking", in conformity with the Tegucigalpa Protocol" (2014: 113). This agenda grew even more in Central America-Mexico Dialogue about democratic security in San Salvador in 2007. There a widely simplified agenda was established: fight drugs, divert resources, organized crime, transnational organizations, illicit firearms trafficking, illicit trafficking of people, protection for victims of illicit trafficking and/or human trafficking, money laundering, gangs, border security, terrorism, security of people and their belongings, legal assistance and extraditions (Source: XXXI Reunión de la Comisión de Seguridad de Centroamérica, 16 de mayo de 2007). For Aguilera the current security agenda "is principally formed by four strands: citizen security, ecological security, risks to security derived from economic-social shortcomings, and the topic of terrorism" (2014: 31) and of course finishes with victims of the paradigm, "the generalization of the insecurity has diverse effects. The most dire is the strengthening of cultural, political, and authoritative elements (2014: 132).

\section{CONCLUSIONS}

This paper has tried to understand Central American thought from the question for the gradual elaboration of agenda of international topics, pointing out 5 moments in the discussion from the beginning of the XX and XXI centuries. The first moment characterized a thought that articulated unionism and anti-imperialism or, at least, anti-US-Americanism. In this setting the proposal was formulated to recreate the Great Homeland that J. Cecilio del Valle had suggested. The second represented a minor change within an important continuity, in regards to the type of discourse as well as the type of institutionalism, emphasizing the relationship between union, democracy, and anti-interventionism. The third highlighted three major topics: the relationship between development and integration, which also marked the previous periods, the defense of basic wealth, and the necessary creation of institutions that 
represent the integrationist will. The fourth was known for the topic of peace being key. This articulated a discourse that capitalized and reformulated previous concepts such as development, democracy, and integration. The fifth formulated open integration oriented towards insertion, associated with sustainable development in environmental terms and above all else, the matter of security.

As one can see, the Central American discussion around international affairs and up to global affairs, through the length of a century, principally has consisted mainly of discussions about the topic union-integration, associating itself with other concepts according to the moments, interrelating it with others, re-signifying it, and re-formulating it...these have been: integration as a return to the federal system, anti-imperialism, development within, peace, outside development, and security. The second great theme has been the defense of sovereignty, understood as anti-interventionism, anti-imperialism, and self-determination. The third, especially during the second half of the period, has been development.

Central American thought has not intended to elaborate theories that are universal or explicative of international phenomena like those that have been attempted by other authors in the region, from nacionalities such as Brazilian, Chilean, and above all else, Argentinian like Raúl Prebisch, Juan Carlos Puig, Samuel P. Guimaraes, Amado Cervo, Raúl Bernal-Meza, Carlos Escudé, among others. The Central American duty in these subjects have been stuck to the circumstantial problems of the region, being exceptional reflections of the best theoretical base, such as Cohen and Rosenthal (1980), pointing to considerations that try to define the "integration" notion beyond results and specific situations, or those of Ethel Abarca ${ }^{5}$ (1998) about states of small dimensions.

\section{FINAL REFLECTIONS}

I take the words of Miguel Gutiérrez Saxe when he states that it is necessary "to rediscover the region to face the obstacles". Actually, it appears to me that a large part of the intellectuality of the region thinks "Central American-like". Gutiérrez Saxe continues: "No country of the region can afford to distance themselves from their neighbors. No one is so powerful or self-sufficient. Rediscovering Central America is more than "being" in Central America. It means, in particular, to expand upon joint actions for administering common assets" (2008: 17).

\footnotetext{
${ }^{5}$ A large quantity of professionals was cited, who recognize themselves as belonging to the field of international relations, as well as thinkers that do not do it. Precisely, what it tries to show is that there exists a reflection about matters that go beyond the N-S, done by people that come from very diverse disciplines. And that especially before the field was constructed.
} 
Not only the countries cannot distance themselves, but the agents either; that is one of the flaws of "statism" that justifies and promotes passivity in civil society. The potential of civil society and the democratic projects are a threat to the vision of omni-security.

The danger of omni-security and the authority derived from this perspectivedespite the sensible precautions of Gabriel Aguilera- betraying the finishing of the assumed US-American agenda. This means to consider everything as a topic of security, but paradoxically not the presence of the USA, a matter that for regional concerns had been the main problem of security for the region until the 1970s because of the expansionists and interventionists aspirations.

Continuing and deepening the development of Central and Latin American thought regarding international topics appears to be something critical in the search for relative autonomy of our intellectual duties. The development of this thought involves cultivating and criticizing our own trajectory, not to exclude readings, although airing them out and renewing them, considering a worldly bibliography from Asia, Africa, and LA about these themes and breaking disciplinary dependence on the academia of the center (see Bernal Meza, 2005 and Devés, 2013).

A discussion about the agenda of thought in regards to international and worldly affairs, specifically in connection with other places in our region, would be very interesting. In this regard, it is important that related careers add to their curriculum the necessary courses for students and professors to continue to better understand the history and potential of our thought about international and worldly matters.

\section{REFERENCES}

Abarca, Ethel. "Algunos elementos teóricos para el análisis de políticas exteriores de pequeños países”, Estudios Internacionales 31 (1998): 88-101.

Aguilera, Gabriel. "América Central: Democratización e integración", Cuadernos Iberoamericanos de Estudios Históricos y Libertades Civiles, Universidad Complutense de Madrid, № 2 (2012): 81-90.

Aguilera, Gabriel. "El camino desconocido. Las nuevas funciones de los ejércitos centroamericanos", Nueva Sociedad, No 138 (julio-agosto, 1995): 120-131.

Antillón, Alvar. La ODECA y el Parlamento Centroamericano. San José, Costa Rica: Editorial Juricentro, 1996. 
Antillón, Alvar. Contadora: ¿Simples buenos oficios o formal mediación? Costa Rica: Universidad Nacional, 1997.

Arévalo, Juan José. Escritos politicos. Guatemala: Tipografía Nacional, 1946.

Bernal-Meza, Raúl. América Latina en el Mundo. El pensamiento latinoamericano y la teoría de las Relaciones Internacionales. Buenos Aires: Grupo Editor Latinoamericano, 2005.

Blanco, Víctor Hugo. "La nueva arquitectura de la integración regional centroamericana a partir de los años 1990: El SICA”. En Soto, Willy y Max Sáurez (Eds.), Centroamérica: Casa común e integración regional. San José, Cosdta Rica: Lara Segura \& Asociados, (2014): 73-87.

Casaus, Marta. "El vitalismo teosófico como discurso alternativo de las elites intelectuales centroamericanas en las décadas de 1920 y 1930. Principales difusores: Porfirio Barba Jacob, Carlos Wyld Ospina y Alberto Masferrer”, REHMLAC, Revista de Estudios Históricos de la Masonería 3 / 1 (noviembre de 2011): 81-120.

Cerdas, Rodolfo. "Seguridad en Centroamérica". En Francisco Rojas Aravena, Bernardo Arévalo de León y Carlos Sojo (Eds.), Sociedad, Estado y fuerzas armadas: La nueva agenda de seguridad en Centromérica. Guatemala: Flacso, (1998): 119-126.

Chapa, María de los Ángeles. "Presencia de Rafael Heliodoro Valle en la Política de Honduras". Boletín del Instituto de Investigaciones Bibliográficas XIII / 1-2 (México, primer y segundo semestres de 2008): 179-211.

CICA. Los pueblos indigenas en el marco de la integración centroamericana. Tegucigalpa: Abya Yala, Centro América, 2007.

Cohen, Isaac. "Funcionalismo e integración centroamericana", Foro Internacional, año IX (octubre - diciembre de 1968), México D.F.: El Colegio de México.

Cohen, Isaac y Rosenthal, Gert. Algunas reflexiones en torno al marco conceptual de la integración centroamericana. Buenos Aires: BID, 1980.

Cuevas, Rafael. Sandino y la intelectualidad costarricense. Nacionalismo antiimperialista en Nicaragua y Costa Rica (1927 y 1934). San José, Costa Rica: EUNED, 2008. 
Delgado, Jaime. "Integración formal, integración real y sociedades civiles en la Centroamérica actual”. En Soto, Willy y Sáurez, Max (Edits.), Centroamérica: Casa común e integración regional. San José, Costa Rica: Lara Segura \& Asociados, (2014): 105-128.

Devés, Eduardo. "Cómo pensar los asuntos internacionales-mundiales a partir de la historia del pensamiento latinoamericano: Análisis de la teorización sobre relaciones internacionales", 17 /1 (2013). Disponible en http://www. unisinos.br/revistas/index.php/historia/article/download/.../1435.

Devés, Eduardo. El Pensamiento Latinoamericano en el Siglo XX. Entre la modernización y la identidad. Tomo II. Desde la CEPAL al Neoliberalismo (1950-1990). Buenos Aires: Biblos, 2009.

García, Teresa. La patria grande centroamericana: La elaboración del proyecto nacional por las redes politicas unionistas. España: Universidad Autónoma de Madrid, 2003.

Giménez, Felipe. "A propósito del libro de Julio Ycaza Tigerino, La cultura hispánica y la crisis de Occidente (1980)", El Catoblepas 8 (octubre de 2002).

Gutiérrez-Saxe, Miguel. "El Estado de la Región (2008): Un informe desde y para Centroamérica", Diálogo Centroamericano. Esquipulas veinte años después: La agenda pendiente, No 52, San José, Costa Rica, 2008.

Hernández Chávez, Alcides. "La nueva integración centroamericana”, Revista de la integración y el desarrollo de Centroamérica, No 49, Banco Centroamericano de Integración Económica, 1992.

Marín, Dunnia y Sáurez, Max. "La ODECA: Intento de integración política centroamericana". En Soto, Willy y Max Sáurez (Eds.), Centroamérica: Casa común e integración regional. San José, Costa Rica: Lara Segura \& Asociados, (2014): 47- 58.

Mendieta, Salvador. (s/f) La enfermedad de Centroamérica. Barcelona: Tipografía Maucci.

Mendieta, Salvador. (s/f) Alrededor del problema unionista americano. Barcelona: Tipografía Maucci, 1934. 
Ordoñez, Jaime y Gamboa, Nuria. Esquipulas, diez años después. ¿Hacia dónde va Centroamérica? San José, Costa Rica: CSUCA, 1997.

Ortega-Durán, Oyden. Contadora y su verdad. Madrid: Editorial Rufino García Blanco, 1985.

Rojas Aravena, Francisco. Costa Rica: Politica exterior y crisis centroamericana. Heredia, Costa Rica: UNA, 1990.

Rojas Aravena, Francisco. "Introducción”. En Luis Guillermo Solís y Francisco Rojas Aravena (Eds.), Crimen organizado en América Latina y el Caribe. San José, Costa Rica: Flacso, (2008): 9-15.

Rojas Aravena, Francisco y Beirute, Tatiana. "La situación de inseguridad en Centroamérica: Problemas y respuestas”, Diálogo Centroamericano. Esquipulas veinte años después: La agenda pendiente, No 52, Fundación Arias, 2008.

Rosenthal, Gert. "Un informe crítico a 30 años de integración en América Latina”, Nueva Sociedad, No 113 (mayo-junio DE 1991): 60-65.

Rosenthal, Gert. "Algunas reflexiones sobre el proceso de integración económica centroamericana". Revista de la integración y el desarrollo de Centroamérica, No 26, Banco Centroamericano de Integración Económica, 1979.

Sáenz, Vicente. Auscultación Hispanoamericana. México: Humanismo, 1954.

Sáenz, Vicente. Paralelismo de la paz y de la democracia. México: UDC, 1946.

Sánchez, Rafael. The politics of Central American Integration. Nueva York-Londres: Routledge, 2009.

Silva, Margarita. "Centroamérica 1850-1950. Los debates fundamentales sobre la unión política regional”. En Soto, Willy y Max Sáurez (Eds.), Centroamérica: Casa común e integración regional. San José, Costa Rica: Lara Segura \& Asociados, (2014): 33-45.

Sol, Ricardo. "Inclusión y construcción de espacios de diálogo y acuerdos, hacia una democracia deliberativa”. En Ricardo Sol. El Desafio de la participación ciudadana en el estado democrático de derecho y retos de la participación ciudadana en la gestión de políticas públicas, en espacios institucionales de los estados centroamericanos. San José, Costa Rica: Flacso, 2012. 
Soto, Willy. "Génesis y evolución del Mercado Común Centroamericano" . En Willy Soto y Max Sáurez (EdS.), Centroamérica: Casa común e integración regional. San José, Costa Rica: Lara Segura \& Asociados, (2014): 59-72.

Torrijos, Omar. El Pensamiento del general Omar Torrijos Herrera. Textos recopilados por la revista Lotería, Panamá, 1999.

Vargas, Armando (1990) "Latinoamericanidad de Figueres", Revista de COPPPAL, Ciudad de México $1 / 1$ (julio-agosto de 1990). Disponible en: http: // www.elespiritudel $48.0 r g /$ docu/h100.html

Villalta, Ana Elizabeth (s/f) "la integración centroamericana, el comercio y el desarrollo". Disponible en: http://www.oas.org/es/sla/ddi/docs/8\%20 -\%20villalta.MR.139-160.pdf

Zeledón Cambronero, Mario. "Pensamiento y vigencia de Vicente Sáenz", Revista de Filosofía, Universidad de Costa Rica XV / 41 (1977): 269-280. 